\title{
Human Rights Perspective in The Indonesia Policy Concerning High Scale Social Restriction in Pandemic Era
}

\author{
Erlina Maria C Sinaga ${ }^{1}$, Mery Christian Putri ${ }^{2}$ \\ \{erlina.sinaga@mkri.id ${ }^{1}$, mery.christian@ mkri.id ${ }^{2}$ \} \\ Center for Research and Case Analysis and Library Management, Constitutional Court of Indonesia, \\ Medan Merdeka Barat Street Number 6, Jakarta, Indonesia ${ }^{12}$
}

\begin{abstract}
The covid-19 pandemic since early 2020 has multiplier effect towards social life activity. Various countries all around the world implemented lockdown policy to decrease the spread of covid-19 even though social activity restraint that becomes part of lockdown could have negative impact. Many experts mentioned that there have been massive de-democratization and the violation of socio-economic rights. The Indonesian government tried to take a win-win solution by implementing Large Scale Social Restraint (Pembatasan Sosial Berskala Besar, PSBB). The practices and implementation of Psbb would be given to each Leader of local government that should be adjusted to the latest potential of covid-19 spread. On one side, this policy can obsolete the spread of Covid-19 and decrease the confirmed case numbers, but on the other hand the enforcement of socio-economic rights is at stake. Many forms of disruption and changes as the impact of the response of Covid-19 handling affects the value and social life of society. The Covid-19 pandemic also raised sectoral inequality that can be seen from the inequality distribution from national resources to region and city or village in getting financial support. This article will analyze the perspective of human rights and constitutionality of government policy concerning the covid-19 handlings in Indonesia. The research will compare it to the policy and regulations made in some ASEAN countries members which have similarities with Indonesia. This is a juridical normative research with comparative and statute approach. This research conclude that the implementation of social restraint could be an effective way to decrease the confirmed Covid-19 cases in Indonesia as long as it is supported by strict regulation followed by the public awareness. The state should guarantee and assure the rights of life of the citizens for the impact of this policy. A good cooperativeness between the government and citizens takes an important role to minimize the impact of Covid-19 prevention.
\end{abstract}

Keywords: socio-economic rights; impact; Covid-19 policy

\section{Introduction}

Since January 2020, Corona Virus Disease (Covidi-19) has infected more than 2.245 .872 people in all around the world. There have been more than 152.000 people confirmed death by the infection of this virus.[1] Indonesia is the fourth largest populated country in the world. By the slow response toward the crises created by the Covid-19 pandemic, it is potential to be the world epicentrum of virus after Wuhan. The irresponsive and inaccurate policy could probably harm millions of people in Indonesia. It could be seen from the policy enacted by the 
government on early January and February 2020. When many countries such as China, South Korea, Italy implemented the city lockdown and close the possibility of cross borders human transportation, Indonesia was trying to attract foreign tourist and businessman from those country to visit Indonesia.

As time went by, after Indonesia government confirmed the first case of Covid-19 on March 2 2020, some regulations and policies related to the Covid-19 handling were initiated. However, it could be considered too late even though an old saying it is always better late than never. The Indonesian government began to enact some policies that prohibit people to travel to Indonesia, limit the travel schedule from and to abroad as South Korea, Italy, Iran, implementing virtual education so that student from school and university could access education from home, close some public space activity and working space, oblige civil servants and employee in private company to work from home.

The legislator and government somehow control the spread and handle the impact of covid-19 by trying to "replicate "the policies that effectively implemented to flattening the curve in some other countries. This replication effort is decided by the government as a its sensitivity about the formulated policies that successfully implemented by other countries. In the meantime, in the field of health facility, the government has provided the necessary stuffs for covid-19 handling that is personnel protective equipment (PPE), masks, medicine, multivitamins, and re-function some hotels and meeting rooms to be special hospital for Covid-19 handling. The Indonesian government has optimized the massive screening Covid19 test whether by rapid test or Polymerase Chain Reaction (PCR) test method[2].

Based on the official website of Covid-19 handling in Indonesia, https://covid19.go.id/peta-sebaran-covid19, the daily increase number of Covid-19 confirmed case was 8.242 on February 8 2021. A month previously, January 82021 the daily increase number was fluctuating with the highest number 14.224 confirmed cases and lowest number 8.692 confirmed cases. The background of the Covid-19 confirmed cases daily decrease number in Indonesia was accompanied with the decrease of Covid-19 tracing and screening test in the society.[3] To decrease the Covid-19 spread, government then implement the LargeScale Social Restraint (Pembatasan Sosial Berskala Besar, hereinafter PSBB).

The detail implemented of PSBB is determined by the Head of local government in each province based on its condition, since every province could have different social cultural and condition. Later on, as some province implemented this policy its impact was found to put aside respect for the protection of human rights. Some forms of human rights violations that occur that were the restriction and limitation of people's expression, the large amount of private company employee getting laid off, the unfulfillment of the access to justice in the due process of law enforcement.

The question rises up then, why is the confirmed Covid-19 cases in Indonesia hasn't reached the stable decrease? is it due to the difficult implementation of policy? are there any other factors? The author assumed that the soar of Covid-19 confirmed cases in Indonesia caused by the late responses of Indonesia government's policy, the weakness coordination amongst stakeholder, the ignorance of society on government's advices, and some facts that governments 'effort to handle Covid-19 could violate the citizen's human rights. Therefore, this article will elaborate and analyse the policies that is enacted by the government and the human rights that is realized in many policies and how it compares to other state's policies and human rights protection. 


\section{Results and Discussion}

\subsection{The Indonesian Government Policies in Handling Covid-19}

In order to prevent the widely spread and transmision of Covid-19 to broader society, the government has created and enacted series of policy to handle it. The policy consists of written and unwritten rules and conduct. The written rules can be seen from many regulations e.g Act, the government regulation, presidential decree, minister regulation, local government regulation, major regulation, and some other kinds of policy that is addressed by governmental leader or beschiking. The unwritten policy that is addressed are usually advices or command that come from government, public figures, traditional leaders, religious leaders which contains prohibitions and appeals related to the prevention and handling of Covid-19.

Here are some examples of written policies in Indonesia: Presidential Decree Number 11 the year 2020 concerning Determination of Public Health Emergencies for Corona Virus Disease 2019 (Covid-19), Act Number 2 the Year 2020 concerning State Financial Policy and Financial System Stability for Handaling Covid-19 Pandemic and/or in the Context of Facing Threats Endagering the National Economy and/or Financial System Stability; Government Regulation Number 21 the year 2020 concerning Large Scale Social Restriction in the Context of Accelerating the Handling of Covid-19; Circular Number 57 the year 2020 on May 282020 concerning the Ectention of the Work From Home Implementation for State Civil Servants; Presidential Decree Number 12 the year 2020 concerning the Determination of Non-Natural Disaster for the Spread of Covid-19 as a National Disaster (Abdullah, 2020) [4].

Policy is the principle chosen by the government to guide the decision making process. Policy is part of government instrument, not only in the sense of government which only concerns the State apparatus, but also governance which touches the management of public resources. Pplicies are decisions or action options that directly regulate the management and distribution of natural, financial, and human resources for the sake of public interest. ${ }^{[5]}$ (Suharto E, 2008). There are many definitions of public policy, most experts emphasize making decisions or government decisions to carry out an action that is considered to have a good impact on its citizens.

Bridgeman stated that (Bridgeman, 2004) public policy can be defined as whatever government choose to do or not to do. It means public policy is the option that is taken by the government whether it contains norms which the society should adhere [6]. Therefore, policy is a statute that contains principles that is made by plan and consistent to solve problem and achieve specific purpose. Hereby the policies that has been implemented in Indonesia during the Covid-19 pandemi as follows:

a. Staying at home policy

The spread of Covid-19 push everybody to stay at home and do all activities from home.

It is an anticipation movement so that the spread of Covid-19 could be limited. In the effort to prevent the spread of Covid-19, the government in many state implement staying at home policy at least for 14 days. This stay at home campaigne aims to minimize any outdoor activity.

b. Social distancing and Physical Distancing Policy

Social distancing and physical distancing are ways that are considered effective in inhibiting the spread of the Covid-19. This extreme limitation of social distance is intended so that the growth rate of confirmed Covid-19 cases will not cause the curve to rise sharply but rather sloping. The sharp curve will cause a high number of infected confirmed cases who require a special paramedical care so that it can cause mass chaos due to an imbalance of public health facilities and infrastructure. 
c. Policy on the use of personal protective equipment (masks)

This is related to the mask movement for all those who campaign for the obligation to wear masks while in public spaces or outside the house. The use of masks aims to protect the users from particles carried through droplets or body fluids containing viruses or bacteria.

d. Working and Studying from Home Policy

This appeal applies to schools, universities and the business world. An order that requires everyone not to leave the house for the safety and health of that person. The order that requires every citizen to stay at home is an effort to prevent the spread of Covid- 19 . There are many activities we can do at home, including exercise and doing sports. Currently, the government has carried out a working from home movement which is very beneficial for some workers in Indonesia. Teaching activity can also be a routine activities while staying at home. Nowadays, most schools, colleges, and other educational institutions implement the online-based learning or e-education.

\section{Policy on suspending all crowd-gathering activities}

The government has made a policy to be able to postpone the implementation of activities that involve large crowd in critical and sensitive situations such as events that are held in conference halls, hotels, or other public service areas.

a. Large Scale Sosial Restriction Policy (Pembatasaan Sosial Berskala Besar, PSBB)

The implementation of large scale social restrictions includes : [7]

- School and working from home policy;

- Restrictions on religious activities;

- Restrictions on social and cultural activities;

- Restrictions on activities in public places or facilities;

- Restrictions on the mode of transportation;

- Restrictions om other activities specifically related to defense and security aspects.

b. New Normal Habit policy

In order to restore the wheels of the economy so that it can return to normal activities as a result of the Covid-19 pandemic, the government has imposed a new normal habitual condition, which is a change in behaviour to continue carrying out to normal activities. But, by continuing to implement health protocols to prevent the possibility of Covid-19 transmission [8] (Minister of Transportation, 2020).

\subsection{The Human Rights Protection in Covid-19 Handling Policy in indonesia and Asean Perspective}

Most of the countries affected by the Covid-19 pandemic have imposed social restriction, isolation policy, regional quarantine and various policies aims at preventing transmissions of the virus. However, the level of effectiveness of each policy certainly different in each region and country. The existence of these various social restrictions has a direct or indirect effect on the fulfillment of human rights. Principally, human rights consists of civil political rights and economic socio-cultural rights. One of the evolutions of moderen human rights is the existence of the International Covenant on Economic Social and Cultural Rights (ICESCR) IN 1966 which in Indonesia was ratified through the Law Number 11 the year 2005 concerning Ratification of the ICESCR.

ICESCR is an international human rights instrument that has become customary international law throough recognition in conventions and other declarations and through jurisprudence and national law [9] (Ilias Bantekas, 2016). Countries in the world are commited 
to realizing human rights, including the fulfillment of progress (progression) of the economic, social, and cultural rights of everyone with the ratification of several international human rights treaties regulating socio-economic rights. ${ }^{[10]}$ (Manisuli Senjoyo, 2016).

Speaking of the economy context, Juan Pablo, a UN expert in the field of debt and human rights (United Nation independent Expert on Debt and Human rights) stated that the health crisis as a result of Covid-19 has brought all parts of the world into economic recession. [11] (Juan Pablo Bohoslavsky, 2020) Andrea Lidwina also describes the analysis that the world economy will bear the burden in the form of an economic representation as a result of Covid19. ${ }^{[12]}$ (Andrea Liwdina, et.al, 2020) This means that the health crisis as a result of Covid-19 can increase with the potential for an economic crisis [13]. (Sarah Joseph, 2020). Covid-19 has resulted in a global public health emergency, a global economic emergency, and a global human rights emergency. The rights set out in the ICESCR are economic rights. Social and cultural and related to the realization of basic needs in human life, including subsistence rights or basic rights. ${ }^{[14]}$ (Amanda Cahill Ripley, et.al, 2018).

Referring to Articles 14-15 of the Civil Covenant and their elaboration in General Comment No. 32 of 2007, the right to a fair trial includes the treatment of the suspect / defendant during and before the trial process, including the right not to be processed legally without any articles being violated. (Based on Article 15 of the ICCPR).

Government policies related to handling Covid-19 often have an impact that is contrary to the human rights situation. A non-governmental organization commission for Missing Persons and Victims of Violence (Komisi Orang Hilang dan Korban Kekerasan, KontraS) participates in monitoring the fulfillment of the state's obligations to protect, respect and fulfill the human rights of everyone living in Indonesia, including monitoring respect for democratic principles in handling COVID -19. Throughout 2020, there were several aspects of human rights violations as a result of the implementation of policies related to the handling of the Covid-19 pandemic.

First, the right to health standards. From the findings reported by the KontraS team, there were several problems related to the Covid-19 referral hospital, for example the lack of access to information, lack of medical personnel, lack of facilities and infrastructure to support health services. It should be realized that access to health services is an inseparable part of universal human rights. The principle of fulfilling health rights is also regulated in General Comment No. 14 of 2000 where the state is obliged to pay attention to the availability, accessibility, acceptance and quality of health services to the public.

Second, the right to information. There are findings that the involvement of the State Intelligence Agency with silent operations has resulted in incomplete dissemination of information to the public, and there have also been many inconsistent statements and confirmations from political elites and state officials regarding the handling of crises in the regions. This does not realize the state's obligation to convey information as stipulated in Article 154 jo 155 of Law Number 36 of 2009 concerning health which stipulates that the government determines and announces the types and spread of diseases that have the potential to be contagious and spread in a short time, as well as in Article 9 paragraph (2) letter d Law Number 14 of 2008 concerning Openness of Public Information, Article 14 of Law Number 39 of 1999 concerning Human Rights, which in essence guarantees the right of everyone to be able to obtain, store, process and convey information.

Third, the right to a fair trial. In the period 5 March-21 April 2020, KontraS found that there were 93 incidents of prosecution by security forces with the threat of civil liberties during the implementation of the PSBB. The enforcement of the PSBB should refer to statutory regulations and not be used as a tool to arbitrarily interpret by law enforcement 
officials in carrying out crowd dispersal. This is because based on the data obtained by KontraS, there are still many regions that have not implemented the PSBB set by the central government but the security forces in these areas have carried out dissolution actions. These actions are certainly contrary to the guarantee of the right to freedom of assembly, where the right to freedom of assembly is guaranteed by law and can be limited by legal and human rights standards.

Fourth, the right to be free from discrimination and stigmatization. Community stigmatization emerged as a result of the government's dissemination of inaccurate information. This resulted in the public getting incomplete information. This non-fulfillment of the right to be free from discrimination and stigmatization confirms the deprivation of information rights to other dimensions of rights. Manfred Nowak stated in his book that there are 4 principles of human rights, namely: universal (universality), indivisibility, interdependent, and interrelated [15] (Manafred Nowak, 2003) This is in line with Article 5 of the Vienna Convention which states that "all human rights are universal, indivisible, interdependent, and interrelated". The principle of indivisibility, which means that human rights, as important as they are for that reason, are not allowed to remove or eliminate certain rights or certain categories of rights from their parts.

The problem is in the implementation of several government policies that actually aim to overcome the impact of Covid-19, often either directly or indirectly unable to fulfill these aspects of the fulfillment of human rights. The supervisory agency for the enforcement of human rights protection in Indonesia, KOMNAS HAM (National Commission on Human Rights) has compiled a rapid research which in essence contains findings and recommendations regarding a human rights perspective policy on the governance of handling Covid-19 [16]. (Kabar Latuharary, 2020) the issue of human rights protection should be the government's duty and responsibility so that there is no discrimination in providing access to health services for every citizen. There are 18 Komnas HAM recommendations as follows:

1. Strengthening legality;

2. Centralized policy platform

3. Regional and proportional quarantine policies

4. Strict crowd and mobilization policy

5. Up-to-date and transparent movement information

6. Reduction of the number of occupancies in correctional institutions and detainees

7. Application of strict sanctions in the form of fines and penalties in various special events

8. Optimal use of technology

9. Direct life support

10. A home education model that does not add to the cost burden for parents

11. Additional medical personnel and health support equipment

12. Guarantee the fulfillment of the rights of medical personnel

13. Development of a special mechanism for persons with disabilities

14. Socialization of stigma elimination for covidi-19 survivors

15. Proportional distribution of medical personnel, volunteers, supporting facilities for handling covid-19,

16. Protection for workers and workers;

17. Policies for Indonesian citizens abroad as well as migrant workers who are in countries with a high spread of covid-19.

18. Maximum health services for confirmation patients, families, and communities.

In fact, there are several things that are closely related to human rights restrictions in the implementation of the government's PSBB policy as one of the policies for handling Covid- 
19, whose enforcement is returned to the local government in accordance with the conditions of the spread of Covid-19. ${ }^{[17]}$ (Ady Thea DA, 2020) First, related to the prohibition of traveling out of town or going home for employees. The absence of solid and clear regulations and the absence of supervision has resulted in this policy being seen as a mere formality. Second, related to restrictions on worship activities in places of worship. Synergy with religious leaders is needed to raise awareness for the community so that they can worship at home. In addition, this is in order to prevent places of worship from becoming points of spread of Covid-19.

Human rights norms and ideas are actually an evolution of thought and various efforts to create a more respectful and dignified life and world order. ${ }^{[18]}$ (Eko Riyadi, 2019). Normatively, Article 1 paragraph (1) of Law Number 39 of 1999 concerning Human Rights regulates those human rights are a set of rights inherent in the nature of human existence as a divine being and are a very mandatory gift to be respected, upheld and protected by state, law, government and everyone for the sake of respect and protection of human dignity.

Talking about the ICESCR rights that have been mentioned in the introduction, economic and social rights are divided into 5 major groups, first, rights at level and at work (Articles 6, 7, and 8); second, rights related to protection guarantees (Articles 9 and 10); third, the right to a decent life and health (Articles 11 and 12); fourth, the right to education (Articles 13 and 14); fifth, the right to cultural participation (Article 15). ${ }^{[19]}$ (Eko Riyadi, 2008). Based on this, the right to health is part of the right to guarantee protection, which is directly related to the right to a decent life.

Everyone has the right to be able to obtain the best standard of health, both physical and mental, as well as health services provided by the state (government). ${ }^{[20]}$ (Firdaus, 2016) The right to health is fundamental to human rights in terms of human dignity. The state must ensure that all people are treated equally by health workers in the effort to protect health. ${ }^{[21]}$ The Indonesian Constitution also provides clear protection that everyone has the right to be able to live in physical and spiritual prosperity, to live in and have a good and healthy environment and to receive health services [22].

The state is also bound by the responsibility for the provision of proper health service facilities and public service facilities [23] to realize good health standards for all people. Then whether the government's policies in handling the Covid-19 pandemic are in accordance with the aspects of protecting human rights both in a global and specific context in accordance with the Indonesian constitution when human rights actually have the principle of indivisibility, interdependence, interrelated, and inalienable [24]

The Indonesian government has responded to the tendency for the lack of fulfillment of human rights during the pandemic in various ways. One of them was the initiation of joint statements of family violence at the UN Human Rights Council with the support of 31 member countries [25] As a follow-up to Komnas HAM and KontraS recommendations, the government has also facilitated the return of more than 169 thousand Indonesian workers abroad and provided assistance to more than 500 million Indonesians who were still abroad during the Covid-19 pandemic. With regard to the implementation of the PSBB, which has been pointed out as an entry point for violating the rights of citizens, in fact as long as the state can guarantee the fulfillment of the rights of its citizens, there will be no human rights violations in the implementation of the PSBB [26] (Petrus Riski, 2020).

The government's efforts include the distribution of basic needs for poor citizens and recorded by the Ministry of Social Affairs, the distribution of free internet quota for students who have to go to school from home [27]. (Falah Aliya, 2020), development of digital infrastructure in all regions remote to maintain the stability of internet connection, 
implementation of pre-employment card program for residents who lost their jobs due to the impact of the Covid-19 pandemic [28]

In the social contract theory [29 (Daya, 2016), the state becomes a duty bearer in the implementation of human rights so that it is fully responsible for the fulfillment, respect and protection of human rights. Therefore, the government must use a humanist approach in issuing its policies in the context of tackling Covid-19. The existence of a humanist approach is faced with a synergy with efforts to respect and enforce the protection of human rights for the entire community.

\subsection{Global Response to the Protection of Human Rights during Pandemic Period}

The European Union Agency for Fundamental Rights (FRA) oversees the fulfillment of people's human rights in the European Union by ensuring four main issues that have become the struggle of society [30]. (Michael O'Flaherty, 2020), namely:

ASEAN held a summit in April 2020 [31] (Lidya Christin Sinaga, 2020) which resulted in several agreements in handling Covid-19. First, the emphasis on transparency among ASEAN members in monitoring human traffic, especially in countries with high population mobility. It is undeniable that ASEAN countries cannot rule out the existence of population connectivity among member countries.

Second, it is necessary to establish a consultation mechanism between ASEAN countries, including increasing the exchange of information on policies implemented in each country, such as restrictions or restrictions on flights. This openness of data is important because its effectiveness will require valid and measurable information data. Third, massive covid-19 checks on the community. As is well known, Singapore and Vietnam are successful examples of covid-19 control in ASEAN because of the development of a local Covid-19 test kit. A country with a large population like Indonesia clearly needs massive simultaneous screening to be able to suppress the growth of Covid-19.

Fourth, the establishment of the ASEAN Covid-19 Response Fund and the ASEAN Center for Infectious Diseases which are hoped to be a form of solidarity for ASEAN countries to resolve the problems of overcoming Covid-19. However, its effectiveness will largely depend on the financial capacity of each member country. The political-economic aspect that underlies the relationship between the state and its citizens can become a challenge for multilateral agencies in managing non-traditional security threats. [32] (Hameiri \& Jones, 2015).

Peter Sands stated that in dealing with Covid-19, the government must learn from the previous pandemic and ensure equitable services for all residents. The state through government policies must ensure protection for everyone without exception, wherever they are, from the threat of infectious diseases. Strengthening the community system in dealing with a pandemic is also important to be able to immediately end a pandemic. The existence of human rights violations also needs to be followed up, especially when this is experienced by citizens who have vulnerabilities [33]. (Peter Sands \& Antonio Zapulla, 2020).

Differences in policies in several countries in Asia in handling Covid-19 are of course caused by differences in conditions in each country, both related to human resources, forms and systems of government, and the socio-cultural conditions of their people. In the following, the authors summarize a comparison of the policies for handling Covid-19 in Asian countries that have socio-cultural conditions that are not much different from Indonesia. 
Table 1. Comparison of Covid-19 Handling Policies in various Asian countries summarized from various sources [34].

\begin{tabular}{|c|c|}
\hline State & Covid-19 Handling Policy \\
\hline Indonesia & $\begin{array}{l}\text { 1. Indonesia implement Large Scale Social Restriction } \\
(P S B B) \text { and currently implement People Activity } \\
\text { Restriction Implementation }(P P K M) \text {. (both are the } \\
\text { implementation of physical distancing \& social activity } \\
\text { restraints) } \\
\text { 2. Centralized special Covid-19 handling hospital } \\
\text { 3. Mass tracing \& rapid test } \\
\text { 4. The limitation of social and transportation movement. } \\
\text { 5. National economy recovery program. }\end{array}$ \\
\hline China & $\begin{array}{l}\text { 1. Lockdown policy } \\
\text { 2. The development of emergency hospital. } \\
\text { 3. Whistle blowing system }\end{array}$ \\
\hline Malaysia & 1. National lockdown policy. \\
\hline Korea Selatan & $\begin{array}{l}\text { 1. Massive screening and Covid-19 test } \\
\text { 2. National lockdown }\end{array}$ \\
\hline Singapura & $\begin{array}{l}\text { 1. The intervention of government for the transparency of } \\
\text { national citizen database. }\end{array}$ \\
\hline Vietnam & $\begin{array}{l}\text { 1. The government provide Mobile Decontamination } \\
\text { Chamber in public spaces. }\end{array}$ \\
\hline Filipina & $\begin{array}{l}\text { 1. Lockdown policy and the restriction of mass media } \\
\text { information. } \\
\text { 2. Transportation restriction from and to abroad. }\end{array}$ \\
\hline Thailand & $\begin{array}{l}\text { 1. Remote education system } \\
\text { 2. The use of robotic system for detecting viruses. }\end{array}$ \\
\hline
\end{tabular}

In terms of available health facilities and the types of drugs used in the Covid-19 healing method, Indonesia has 140 Covid-19 referral hospitals spread across Indonesia, while India has 7740 Covid-19 referral health facilities. Meanwhile, the drugs used in Indonesia consist of several drug choices, namely 1) opinavir-ritonavir-azithromycin; 2) Lopinavir-ritonavirdoxycycline; 3) Lopinavir-ritonavir-clarithromycin; 4) Hydroxychloroquine-azithromycin; 5) Hydroxychloroquine-doxycycline; 6) Blood plasma therapy. Meanwhile, India uses the following medical options: Hydroxychloroquine, Favipiravir, Remdesivir, Tocilizumab, Itolizumab, Dexamethasone, Methylprednisolone, and blood plasma therapy. The treatment formulation is based on collaborative research between the State Intelligence Agency and several university research institutions that can reduce the amount of virus present in the body when a person is confirmed positive for Covid-19 [35]. 


\section{Conclusion}

The government has a responsibility towards its citizens, especially in the case of the Covid-19 pandemic. To realize the aspirations of the state as a welfare state, the government must implement various policies that can be a solution to any problems that have an impact due to the Covid 19 pandemic. In addition, respect for human rights in all spectrums including economic, social, cultural, social rights politics will be fundamental to the successful response to handling covid-19, restoring the economy and aspects of public health. It is hoped that the covid-19 global pandemic will not be an excuse for the government (state) to formulate policies that are repressive and tend to violate human rights. The government in formulating policies must really consider respect and respect for the protection of human rights.

\section{References}

[1] World Health Organization. (2020). 2019 Novel Coronavirus (2019 nCoV): Strategic Preparedness and Response Plan. February, 28. Retrieved from https://www.who.int/publications-detail/strategicpreparedness-and-response-planfor-the-new-coronavirus

[2] Leo Agustino, "Analisis Kebijakan Penanganan Wabah Covid-19: Pengalaman Indonesia, “ Jurnal Borneo Administrator, hlm 260.

[3] Dicky Budiman, Epidemiolog, Griffith https://kabar24.bisnis.com/read/20210301/15/1362204/update-covid-19-1-maret-kenaikan-kasuspositif-jauh-di-bawah-kasus-sembuh

[4] Abdullah, I. (2020). Psychological Trauma: Theory, Research, Practice, and Policy COVID-19: Threat and Fear in Indonesia.

[5] Suharto, E. (2008). Kebijakan Sosial Sebagai Kebijakan Publik; Peran pembangunan kesejahteraan sosial dan pekerjaan sosial dalam mewujudkan negara kesejahteraan (welfare state) di Indonesia. Penerbit Alfabeta.

[6] Bridgeman, P. and G. D. (2004). The Australian Policy Handbook. Allen and Unwin.

[7] Pasal 13 ayat 1 Peraturan menteri kesehatan republik indonesia nomor 9 tahun 2020 tentang pedoman pembatasan sosial berskala besar dalam rangka percepatan penanganan corona virus disease 2019 (covid-19)

[8] https://hubla.dephub.go.id/ksopmuarasabak/page/news/read/7601/kemenhub-bersiap-masuki-newnormal-di-subsektor-transportasi-laut

[9] Ilias Bantekas dan Lutz Oette, International Human Rights Law and Practice, Cambridge: Cambridge University Press, 2016, p. 18.

[10] Manisuli Senjoyo, Social and Cultural Rights in international Law (2nd Edition), Oxford: Hart, 2016, p. 18.

[11] Juan Pablo Bohoslavsky, 2020, “covid-19 Economy vs Human Rights: misleading Dichotomy", Health and Human Rights Journal, https://www.hhrjournal.org/2020/04/covid-19-economy-vshuman-rights-a-misleading-dichotomy/ accesed March 102021.

[12] Andrea Lidwina, Dwi Hadya Jayani, dan Yoshepa Pusparisa "Ekonomi Dunia menanggung Beban Covid-19" dalam Mei Susanto, "Ekonomi versus Hak Asasi Manusia dalam Penanganan Covid-19: dikotomi atau Harmonisasi” Jurnal HAM, Vol. 11 Nomor 2 Agustus 2020. P. 302.

[13] Sarah Joseph, "COVID-19 and Human Rights: Past, present, and Future", Grifith Law School Research Paper 20, Number 3, 2020, p. 1-11.

[14] Amanda Cahill Ripley dan Diane Hendrick, Economic Social and Cultural Rights and Sustaining Peace: an Introduction (Geneva: Frieidrich Ebert Stiftung, 2018), p. 13.

[15] Manfred Nowak, 2003. Introduction to the International Human Rights Regime, Leiden : Martinus Nijhoff Publisher. 
[16] Kabar Latuharary, "Problematika HAM Pada Masa Pandemi Covid-19", https://www.komnasham.go.id/index.php/news/2020/7/1/1466/problematika-ham-pada-masapandemi-covid-19.html

[17] Ady Thea DA, "Lima Catatan KOMNAS HAM terhadap Pelaksanaan PSBB", https://www.hukumonline.com/berita/baca/lt5ea934767380c/lima-catatan-komnas-ham-terhadappelaksanaan-psbb/

[18] Eko Riyadi, Hukum Hak Asasi Manusia : Perspektif Internasional, Regional, dan nasional (Depok: Rajawali Pers, 2019), p. 10

[19] Eko Riyadi, Hukum Hak Asasi Manusia: Perspektif Internasional, Regional, dan Nasional, 2018. Depok: Rajawali Press.

[20] It is stipulated on Article 12 ICCPR (International Covenant on Civil dan Political Rights) which was ratified by the Act Number 11 the year 2005 concerning the ratification of ICCPR.

[21] Firdaus, "Pemenuhan Hak atas Kesehatan bagi Penyandang Skizofrenia di Daerah Istimewa Yogyakarta", Jurnal Ilmiah Kebijakan Publik 10, Nomor 1, 2016, 87-103.

[22] Article 28H Indonesia 1945 Constitution.

[23] Article 34 Indonesia 1945 Constitution.

[24] UNAIDS, Rights in the Time of COVID-19 : Lesson from HIV for an Effective, Community-Led Response, Geneva, 2020.

[25] Kementerian Hukum dan Hak Asasi Manusia“Pandemi Jangan Halangi Pemenuhan Hak Asasi”, https://www.kemenkumham.go.id/berita/cegah-pandemi-perburuk-pemenuhan-hak-asasimasyarakat accesed March 162021.

[26] Petrus Riski, "PSBB Tidak Melanggar HAM, Tapi Negara Wajib Pastikan Hak Warga Terpenuhi", https://www.voaindonesia.com/a/psbb-tidak-melanggar-ham-tapi-negara-wajib-pastikan-hakwarga-terpenuhi/5423217.html accesed March 162021.

[27] Falah Aliyah, “ “,http://rdk.fidkom.uinjkt.ac.id/index.php/2020/12/10/hari-ham-internasionalupaya-pemenuhan-ham-di-masa-pandemi/ accesed March 162021.

[28] Kementerian Kominfo, "Buka Gelombang 12 Program Kartu Prakerja, kembangkan Kompetensi dan Perlindungan Sosial Masa Pandemi, https://kominfo.go.id/content/detail/32882/bukagelombang-12-program-kartu-prakerja-kembangkan-kompetensi-dan-perlindungan-sosial-masapandemi/0/berita accesed March 162021.

[29] Daya Negri Wijaya, "Kontrak Sosial Menurut Thomas Hobbes dan John Locke",. Jurnal Sosiologi Pendidikan Humanis, Vol.1 No.2 2016

[30] Michael O’Flaherty, "Protect Human Rights and Public Health in Fighting Covid-19”, press release of European Union Agency for Fundamental Rights, https://fra.europa.eu/en/news/2020/protecthuman-rights-and-public-health-fighting-covid-19 "Wabah Covid-19 Bukan Alasan untuk Mengorbankan HAM dan demokrasi", https://kontras.org/2020/05/11/15985/ "3 Perawat RSUD Bung Karno diusir dari Indekos”, https://regional.kompas.com/read/2020/04/27/16500591/3 perawat-rsud-bung-karno-solo-diusir-dari-indekos

[31] Lidya Christin Sinaga, "ASEAN dan Solidaritas Regional Menghadapi Covid-19", http://www.politik.lipi.go.id/kolom/kolom-1/politik-internasional/1359-asean-dan-solidaritasregional-menghadapi-covid-19

[32] Hameiri, Shahar, \& Jones, Lee, 2015. Governing Borderless Threats: Non-Traditional Security and the Politics of State Transformation, Cambridge: Cambridge University Press.

[33] Peter Sands \& Antonio Zappulla, "Put Human Rights at the Center for Our Battle against Covid19.", December 12 2020, https://www.thejakartapost.com/academia/2020/12/12/put-human-rightsat-the-center-of-our-battle-against-covid-19.html accesed March 92021.

[34] "Beda Cara RI dan Negara Lain Tangani Virus Corona", https://www.cnnindonesia.com/internasional/20200303155023-106-480140/beda-cara-ri-dannegara-lain-tangani-virus-corona Mardella Savitri Murtisari, "Beda Cara Indonesia dan 5 Negara Asia Tenggara Tangani Covid-19", https://hot.liputan6.com/read/4206542/beda-cara-indonesiadan-5-negara-di-asia-tenggara-tangani-covid-19 
[35] "Mengenal Kegunaan 5 Obat Kombinasi untuk Lawan Covid-19." http://indonesiabaik.id/infografis/mengenal-kegunaan-5-obat-kombinasi-untuk-lawan-covid-19 accesed March 162021. 